\title{
Identification and antibiogram of Haemophilus parasuis circulating in pig farms in some southern provinces of Vietnam
}

\author{
Quynh T. X. Luong ${ }^{1}$, Duong T. T. Do ${ }^{1}$, Phuong T. Hoang ${ }^{2}, \&$ Phat X. Dinh ${ }^{1}$ \\ ${ }^{1}$ Department of Biotechnology, Nong Lam University, Ho Chi Minh City, Vietnam \\ ${ }^{2}$ Sanphar Veterinary Diagnosis Research Center, Ho Chi Minh City, Vietnam
}

\begin{abstract}
ARTICLE INFO
Research Paper

Received: January 09, 2018

Revised: April 16, 2018

Accepted: June 07, 2018

\section{Keywords}

Antibiotic resistance

Haemophilus parasuis (HPS)

PCR

Pigs

Polyserositis

\section{${ }^{*}$ Corresponding author}

Dinh Xuan Phat

Email: dinhxuanphat@hcmuaf.edu.vn
\end{abstract}

\begin{abstract}
Haemophilus parasuis (HPS) causes polyserositis in swine and is characterized by pneumonia, pleurisy, peritonitis, cardiomyopathy, arthritis and meningitis. To assess the current status of antibiotic resistance of HPS in industrial pig farms, 245 specimens were collected to isolate HPS on chocolate (PVX) supplemented with NAD. A total of $51 / 245$ specimens had suspected HPS colonies $(20.8 \%)$ and those colonies were subsequently identified by traditional methods (gram staining and biochemical tests) in combination with PCR using primers specific to a fragment of $275 \mathrm{bp}$ of peptidase M1 gene. Twenty-one colonies (8.6\%) were identified as HPS and then were tested for resistance to the nine antibiotics which are popularly used in swine farms. The results of the antibiogram showed that all of these HPS were multiresistant bacteria. The percentage of isolates resistant to 7 types, 6 types and 5 types of antibiotics was $33.33 \%, 28.6 \%$ and $23.8 \%$ respectively. Resistance rate was highest forty losin (91\%), followed by tilmicosin (81\%), tulathromycin (62\%), enrofloxacin $(62 \%)$, lincomycin/spectinomycin (57\%), amoxicillin (52\%), florfenicol (48\%); ceftiofur (10\%) and doxycycline (5\%). These findings pose a big concernabout the antibiotic resistance of HPS in pigs and that measures should be taken soon to improve this situation.
\end{abstract}

Cited as: Luong, Q. T. X., Do, D. T. T., Hoang, P. T., \& Dinh, P. X. (2018). Identification and antibiogram of Haemophilus parasuis circulating in pig farms in some southern provinces of Vietnam. The Journal of Agriculture and Development 17(5), 68-76. 


\title{
Định danh và xét nghiệm kháng sinh đồ vi khuẩn Haemophilus parasuis lưu hành trong trại chăn nuôi heo trên địa bàn một số tỉnh phía Nam Việt Nam
}

\author{
Lương Thị Xuân Quỳnh ${ }^{1}$, Đỗ Thị Thùy Dương ${ }^{1}$, Hoàng Thị Phượng ${ }^{2}$ \& Đinh Xuân Phát ${ }^{1 *}$ \\ ${ }^{1}$ Bộ Môn Công Nghệ Sinh Học, Trường Đại Học Nông Lâm TP. Hồ Chí Minh, TP. Hồ Chí Minh \\ ${ }^{2}$ Trung Tâm Nghiên Cứu Chẩn Đoán Bệnh Thú Y Sanphar, TP. Hồ Chí Minh
}

\author{
THÔNG TIN BÀI BÁO \\ Bài báo khoa học \\ Ngày nhận: 19/01/2018 \\ Ngày chỉnh sửa: 16/04/2018 \\ Ngày chấp nhận: 07/06/2018

\section{Từ khóa} \\ Bệnh viêm đa thanh dịch \\ Đề kháng kháng sinh \\ Haemophilus parasuis (HPS) \\ Heo \\ PCR \\ * Tác giả liên hệ \\ Đinh Xuân Phát \\ Email: dinhxuanphat@hcmuaf.edu.vn
}

\section{TÓM TẮT}

Haemophilus parasuis (HPS) gây bệnh viêm đa thanh dịch với những biểu hiện viêm phổi, màng phổi, phúc mạc, xoang bao tim, khớp, và viêm màng não trên heo. Để đánh giá hiện trạng đề kháng kháng sinh của vi khuẩn HPS trên các trại heo công nghiệp, 245 mẫu bệnh phẩm được thu thập nhằm phân lập HPS, định danh và xét nghiệm kháng sinh đồ. Tổng số 51/245 mẫu có khuẩn lạc nghi ngờ $\operatorname{HPS}(20,8 \%)$ và được định danh bằng phương pháp nhuộm gram, xét nghiệm sinh hóa kết hợp với phương pháp PCR với cặp mồi phát hiện gen mã hóa peptidase M1 có kích thước sản phẩm khuếch đại 275 bp. Kết quả khuẩn lạc trong 21 mẫu $(8,6 \%)$ được xác định là HPS và được kiểm tra tính kháng đối với 09 loại kháng sinh thông dụng. Kết quả kháng sinh đồ cho thấy các HPS này đều có tính đa kháng. Số vi khuẩn kháng với 7 loại, 6 loại và 5 loại kháng sinh lần lượt là $33,33 \%, 28,6 \%$ và $23,8 \%$. Trong đó, tỷ lệ đề kháng là cao nhất với tylosin $(91 \%)$, tiếp đó là tilmicosin $(81 \%)$, tulathromycin $(62 \%)$, enrofloxacin (62\%), lincomycin/spectinomycin $(57 \%)$, amoxicillin $(52 \%)$, florfenicol $(48 \%)$; thấp nhất là ceftiofur $(10 \%)$ và doxycycline $(5 \%)$. Số liệu này cho thấy tình hình đề kháng kháng sinh ở vi khuẩn HPS trên heo là rất đáng quan tâm và cần sớm có biện pháp góp phần cải thiện tình trạng này.

\section{1. Đặt Vấn Đề}

Haemophilus parasuis (HPS) là vi khuẩn gây bệnh Glässer, còn gọi là bệnh viêm đa xoang và đa khớp trên heo với các đặc điểm lâm sàng như viêm đa thanh mạc có fibrin, viêm đa khớp và viêm màng não, viêm màng ngoài tim ở heo con từ 4 6 tuần tuổi (Nedbalcova \& ctv., 2006; Olvera \& ctv., 2006). HPS là trực khuẩn Gram âm, thuộc họ Pasteurellaceae, chi Haemophilus, chúng được tìm thấy đầu tiên vào năm 1913 bởi Glässer. Vi khuẩn HPS hiện diện ở hầu hết các nước có ngành chăn nuôi heo phát triển và tỷ lệ nhiễm của nó gần như là $100 \%$ trong các trang trại chăn nuôi heo (Amano \& ctv., 1994; Oliveira \& Pijoan, 2004). Vi khuẩn này thường cư trú ở đường hô hấp trên của heo với đa số các chủng không độc lực có thể được phân lập từ khoang mũi, amidan và khí quản của heo khỏe mạnh. Các chủng độc lực gây bệnh thường được tìm thấy ở các cơ quan có biểu hiện bệnh.

HPS hiện nay được phân loại thành ít nhất 15 serovar khác nhau nhưng còn rất nhiều chủng thực địa được phân lập nhưng không thể xác định được chủng huyết thanh (Lawrence \& Bey, 2015). Trong đó, chủng 4, 5, 13, 14 được xem là các chủng độc lực cao và gây bệnh lâm sàng nghiêm trọng trên heo. HPS thường là vi khuẩn kế phát trên heo bị bệnh tai xanh (PRRS) cùng với các vi khuẩn gây bệnh đường hô hấp khác như $M y$ coplasma hyopneumoniae, Pasteurella multocida, Streptococcus suis type 2 và Bordetella bronchiseptica (Brockmeier \& ctv., 2002). Theo Lam (2013), HPS có liên quan đến $17,5 \%$ số ca bệnh đường hô hấp trên những heo được phát hiện có nhiễm virus PCV2. HPS thường được phân lập từ 
niêm mạc mũi, hạch hạnh nhân, niêm mạc khí phế quản (Nedbalcova \& ctv., 2006). Nội độc tố của vi khuẩn này gây ra các cục huyết khối nhỏ trong mạch máu, góp phần gây tắc mạch, phù thủng nhiều mô cơ quan (Amano \& ctv., 1994). HPS là nguyên nhân hàng đầu gây tử vong ở những đàn heo con từ 4 - 6 tuần tuổi khi chúng trải qua các giai đoạn stress (cai sữa, vận chuyển), trong điều kiện vệ sinh chuồng trại kém, thú có hệ miễn dịch kém hoặc bị viêm nhiễm tiên phát với những tác nhân gây suy yếu miễn dịch như virus dịch tả, virus PRRS, virus PCV2, Mycoplasma hyopneumoniae,...

Ở các nước tiên tiến, HPS cũng được ghi nhận đang lưu hành với tần suất cao tại các trại chăn nuôi công nghiệp. MacInnes \& ctv. (2008) ghi nhận sự hiện diện của HPS trên $96 \%$ tổng số trang trại được khảo sát tại Canada. Tương tự, tại Đức, khảo sát trên heo rừng cho thấy có $74,2 \%$ heo mang trùng (Reiner \& ctv., 2009).

Nhiều nhóm kháng sinh đã từng được chỉ định dùng một cách thường xuyên và phổ biến cho mục đích phòng và trị bệnh do HPS gây ra trên heo tại nhiều nước trên thế giới như macrolide, $\beta$-lactam, phenicol, sulfonamide và tetracycline (Dayao \& ctv., 2016). Tuy vậy, gần đây nhiều báo cáo ghi nhận tình trạng đề kháng của HPS đối với nhiều loại kháng sinh trên lâm sàng như đối với enrofloxacin, trimethoprim, sulfamethoxazole, tilmicosin và tulathromycin (Zhou \& ctv., 2010; Dayao \& ctv., 2016). Theo báo cáo của cơ quan quản lý sức khỏe vật nuôi và cây trồng Vương Quốc Anh (APHA, 2016), bệnh do HPS gây ra có xu hướng tăng dần từ khoảng năm 2012. Đồng thời, sự đa dạng của các dấu hiệu lâm sàng và sự tương đồng về triệu chứng và bệnh tích so với các bệnh đường hô hấp khác làm bệnh Glässer khó được chẩn đoán một cách chính xác, dẫn đến việc sử dụng phác đồ kháng sinh trong thời gian dài có thể gây ra tình trạng đề kháng kháng sinh ở HPS như đã được báo cáo ở Trung Quốc và Tây Ban Nha, nơi mà phần lớn các chủng đã kháng với enrofloxacin và trimethoprim (Howell \& ctv., 2015).

Hiện nay, việc chẩn đoán và định danh vi khuẩn HPS có thể được tiến hành thông qua việc nuôi cấy vi khuẩn kết hợp với các xét nghiệm sinh hóa hoặc thông qua các kỹ thuật như sinh học phân tử như ELISA, PCR (Nedbalcova \& ctv., 2006; Wang \& ctv., 2012). Tại Việt Nam, không có nhiều nghiên cứu về dịch tễ của vi khuẩn HPS cũng như tính đề kháng kháng sinh của vi khuẩn này. Các báo cáo về sự hiện diện và gây bệnh trên trang trại của HPS hiện nay hầu hết đều bắt nguồn từ các tài liệu thương mại mang tính quảng bá sản phẩm (Nguyen, 2015). Để đánh giá hiện trạng lưu hành và tình trạng đề kháng kháng sinh của vi khuẩn HPS tại Việt Nam, chúng tôi tiến hành phân lập, định danh bằng phương pháp sinh hóa kết hợp với $\mathrm{PCR}$ và kiểm tra tính kháng kháng sinh bằng phương pháp khuếch tán trên đĩa thạch đối với vi khuẩn này trên heo công nghiệp tại một số trang trại thuộc miền nam Việt Nam.

\section{Vật Liệu và Phương Pháp Nghiên Cứu}

\subsection{Vật liệu}

\subsection{1. Đối tượng nghiên cứu}

HPS được phân lập từ mẫu bệnh phẩm thu thập từ xoang mũi, phổi hoặc từ dịch thu được từ xoang khớp, xoang bao tim, xoang ngực của heo có các triệu chứng bệnh đường hô hấp như sốt, ho, hắt hơi, sổ mũi, khó thở, thở bụng,...

\subsubsection{Phương pháp lấy mẫu}

Các loại mẫu khác nhau được thu thập và phân tích. Mỗi mẫu đại diện cho một cá thể heo riêng biệt.

- Mẫu xoang mũi: thu thập từ heo sống, bằng cách dùng tăm bông (Swab) đưa vào sâu trong xoang mũi thông qua lỗ mũi những con có biểu hiện lâm sàng của bệnh như heo bị suy hô hấp, kèm viêm khớp. Mẫu swab được lưu trữ trong môi trường thạch ống (Amies medium, COPAN Italia, mã số sản phẩm: D-51588).

- Mẫu mô: đối với các heo được phép mổ khám lấy mẫu xét nghiệm, các loại mẫu khác nhau có thể được thu thập, bao gồm phổi, dịch hoặc các mảng fibrin trong xoang ngực, xoang bao tim. Mẫu được thu thập và bảo quản bằng dụng cụ vô trùng. Phòng thí nghiệm sẽ lựa chọn một loại mẫu nói trên để phân lập vi khuẩn.

Sau đó, mẫu được vận chuyển về phòng thí nghiệm nội trong 24 tiếng và được bảo quản ở điều kiện mát $\left(4^{0} \mathrm{C}\right)$ bằng thùng chứa chuyên biệt.

Theo đó, 245 cá thể heo đã được thu thập và phân tích mẫu (gồm 156 mẫu phết mũi; 89 mẫu mô phổi, dịch hoặc các mảng fibrin xoang bao tim) từ các trại heo tư nhân thuộc khu vực Đồng Nai, Bình Dương, và một số tỉnh thuộc Miền Tây Nam Bộ từ tháng 6/2016 đến tháng 10/2017. 


\subsubsection{Kháng sinh}

Tulathromycin (TUL) 30 jg (Condalab 7374, Spain), florfenicol (FFC) $30 \mu \mathrm{g}$ (Oxoid CT1754B, UK), tilmicosin (TIL) $15 \mu \mathrm{g}$ (Oxoid CT1756, UK), tylosin (TYL) $30 \mu \mathrm{g}$ (Condalab 7376, Spain), doxycycline (DO) $30 \mu \mathrm{g}$ (Oxoid CT0018, UK), enrofloxacin (ENR) $5 \mu \mathrm{g}$ (Oxoid CT0639, UK), amoxycillin (AMX) $25 \mu \mathrm{g}$ (Oxoid - CT0061, UK), ceftiofur (EFT) $30 \mu \mathrm{g}$ (Oxoid CT1751B, UK), lincomycin/spectinomycin (L-2) $109 \mu \mathrm{g}$ (Oxoid - CT1757B, UK). Những dĩa giấy này được tẩm sã̃n với một nồng độ kháng sinh tiêu chuẩn trên bề mặt đĩa.

\subsection{4. Địa điểm phân tích mẫu}

Thí nghiệm được tiến hành trong thời gian từ 3/2016 đến 10/2017 tại: 1/ Phòng thí nghiệm Công Nghệ Gene (Bio-313) - Bộ môn Công Nghệ Sinh Học, Trường Đại học Nông Lâm TP. Hồ Chí Minh và $2 /$ Trung Tâm Nghiên Cứu Chẩn Đoán Bệnh Thú Y Sanphar, thuộc Trại Thực Nghiệm Thủy Sản, Trường Đại học Nông Lâm TP.HCM. Địa chỉ: đường số 11, Khu phố 6, P. Linh Trung, Q. Thủ Đức, TP. Hồ Chí Minh.

\subsection{Phương pháp nghiên cứu}

\subsubsection{Phương pháp phân lập vi khuẩn}

Mẫu tăm bông phết xoang mũi: lăn đầu tăm bông lên một góc môi trường thạch chocolate rồi dùng que cấy vô trùng cấy đều trên môi trường.

Mẫu dịch xoang, mảng fibrin: đặt trực tiếp giọt dịch xoang hoặc dùng kẹp vô trùng gắp mảng fibrin và chấm trực tiếp lên một góc môi trường thạch rồi dùng que cấy vô trùng ria đều trên môi trường.

Mẫu phổi: cắt một phần mô ở vùng ranh giới giữa mô bệnh và mô lành. Sau đó mẫu được cắt nhỏ rồi đưa vào dung dịch $\mathrm{PBS} \mathrm{pH}=7,2$ (phosphate buffered saline), vortex khoảng 30 giây rồi dùng micropipette hút $100 \mu \mathrm{L}$ huyễn dịch đưa vào môi trường thạch chocolate. Dùng que chan vô trùng chan đều ra mặt đĩa, khi mặt thạch khô thì đĩa được đặt vào tủ ủ (Tonpitak, 2010).

Môi trường nuôi cấy được sử dụng là môi trường chocolate agar (GC base REF 228950Difco) bổ sung $5 \%$ máu cừu (defibrin-Công ty Nam Khoa, Việt Nam) và yếu tố V (Nicotinamide Adenine Dinucleotide - Yếu tố VX, Công Ty Nam Khoa, Việt Nam). Đĩa cấy được ủ ở $37^{0} \mathrm{C}$ trong thời gian 18 - 24 giờ trong điều kiện vi hiếu khí (5 - 10\% $\mathrm{CO}_{2}$, Microgen 2,5L, OxoidCN 0025A) (Markey \& ctv., 2013).

Khuẩn lạc Haemophilus spp. mọc trên môi trường Chocolate agar có hình dạng nhỏ 0,5 $1 \mathrm{~mm}$, viền đều, như giọt nước, không tan huyết.

Sau đó, các khuẩn lạc nghi ngờ Haemophilus spp. được khẳng định là vi khuẩn HPS bằng các phản ứng sinh hóa theo hướng dẫn của Markey \& ctv. (2013) trước, kết quả phù hợp sẽ được tiếp tục xác định bằng phương pháp PCR. Cụ thể, khuẩn lạc được ghi nhận là vi khuẩn HPS nếu cho kết quả:

Âm tính với phản ứng hemolysis, CAMP, urease, indole.

Dương tính với catalase.

Kết quả PCR dương tính.

\subsubsection{Phương pháp PCR xác định HPS}

- Ly trích DNA vi khuẩn:

DNA của vi khuẩn được ly trích theo phương pháp sốc nhiệt (Espinosa \& ctv., 2013). Khuẩn lạc được thu nhận từ môi trường nuôi cấy bằng tăm bông và hòa tan vào $0,5 \mathrm{~mL} \mathrm{PBS} 1 \mathrm{X}$. Dịch khuẩn được đun sôi ở $100^{\circ} \mathrm{C}$ trong 5 phút và được làm lạnh ở $-20^{\circ} \mathrm{C}$ trong 10 phút. Dịch nổi được thu lại và sử dụng trong phản ứng PCR sau khi đã ly tâm ở $3000 \mathrm{~g}$ trong 10 phút.

- Chương trình PCR xác định vi khuẩn HPS:

Chương trình PCR xác định HPS được kế thừa từ nghiên cứu của Howell \& ctv. (2015) với cặp primer HPSspp khuếch đại sản phẩm dài 275 bp thuộc vùng bảo tồn cao trong hệ gen lõi mã hóa protein peptidase $\mathrm{M} 1$ của vi khuẩn này. Trình tự primer gồm primer xuôi HPSsppF 5' ACAACCTGCAAGTACTTATCGGGAT-3' và primer ngược HPSsppR 5' TAGCCTCCTGTCT GATATTCCCACG-3'. Đối chứng dương là vi khuẩn HPS thuộc Phòng Vi Sinh - Công ty Sanphar. Vi khuẩn này được phân lập từ thực địa, xét nghiệm sinh hóa và $\mathrm{PCR}$ với cặp primer HPSspp; đồng thời, sản phẩm $\mathrm{PCR}$ này được giải trình tự trong nghiên cứu của Chiu (2017). Vi khuẩn đối chứng dương được tái kiểm tra bằng các phản ứng sinh hóa tiêu biểu để định danh HPS trước khi dùng trong thí nghiệm của nghiên cứu này.

Tổng thể tích thành phần phản ứng $\mathrm{PCR}$ đạt $30 \mu \mathrm{L}$ với $15 \mu \mathrm{L}$ master mix; $1 \mu \mathrm{L}$ lần lượt primer xuôi, ngược; $2 \mu \mathrm{L}$ DNA khuôn mẫu và $11 \mu \mathrm{L}$ nước 
tinh sạch không chứa nuclease. Chu trình nhiệt bao gồm giai đoạn tiền biến tính $95^{\circ} \mathrm{C}$ trong 5 phút, theo sau là 35 chu kỳ với các giai đoạn: biến tính $95^{0} \mathrm{C}$ trong 20 giây, bắt cặp $57^{0} \mathrm{C}$ trong 30 giây, kéo dài $72^{\circ} \mathrm{C}$ trong 30 giây và cuối cùng là giai đoạn hậu kéo dài $72^{0} \mathrm{C}$ trong 5 phút.

- Phương pháp kiểm tra tính nhạy cảm kháng sinh của HPS:

Các phân lập vi khuẩn được khẳng định là HPS bằng các phản ứng sinh hóa và phản ứng PCR đã được kiểm tra tính nhạy với kháng sinh bằng phương pháp khuếch tán trên thạch theo hướng dẫn của tài liệu CLSI M31-A2 (Shryock\& ctv., 2002) và CLSI M45 (Hindler \& ctv., 2016). Môi trường được sử dụng là thạch Muller-Hinton chocolate agar (Difco, Mỹ) bổ sung BBL ${ }^{\mathrm{TM}}$ IsoVitaleX ${ }^{\text {TM }}$ Enrichment (Difco, Mỹ). Chọn 3-5 khuẩn lạc thuần được nuôi trên đĩa chocolate agar qua đêm, sử dụng que cấy vòng chuyển sinh khối khuẩn lạc vào ống chứa $4-5 \mathrm{~mL}$ môi trường MullerHinton broth (MHB) (Merck) để tạo dịch huyền phù. Hiệu chỉnh độ đục của dịch huyền phù bằng cách so với thang đục chuẩn $0.5 \mathrm{MacFaland}$ (tương đương với mật độ tế bào là 1 đến $4 \times$ $108 \mathrm{CFU} / \mathrm{mL}$. Đặt các đĩa giấy tẩm kháng sinh đã biết sẵn nồng độ nhất định lên bề mặt đĩa và ủ các đĩa ở $35 \pm 2{ }^{0} \mathrm{C}$ trong điều kiện $5 \% \mathrm{CO}_{2}$ từ 16 đến 18 tiếng. Sau thời gian nuôi ủ, vòng kháng khuẩn được đo kích thước để xác định sự đề kháng, nhạy cảm và trung gian của kháng sinh đối với HPS.

\section{Kết Quả và Thảo Luận}

\subsection{Kết quả phân lập và định danh vi khuẩn HPS trên heo}

Sau thời gian nghiên cứu với tổng số 245 mẫu bệnh phẩm được thu thập từ 245 cá thể heo khác nhau và được xét nghiệm trong thời gian từ $6 / 2016$ đến $10 / 2017$, nhiều loại vi khuẩn có liên quan đến bệnh đường hô hấp trên heo đã được phát hiện. Trong đó, khuẩn lạc nghi ngờ Haemophilus spp. được phân lập từ 51/245 mẫu (20,8\%).

Trong 51 mẫu nghi ngờ Haemophilus spp. nêu trên, sau khi xét nghiệm bằng các phản ứng sinh hóa và kĩ thuật PCR, có 21/51 mẫu thỏa mãn các điều kiện được đặt ra. Các khuẩn lạc của 21 mẫu này cho kết quả âm tính với các xét nghiệm tan huyết, CAMP, urease, indole và dương tính với catalase. Đồng thời xét nghiệm PCR cho kết

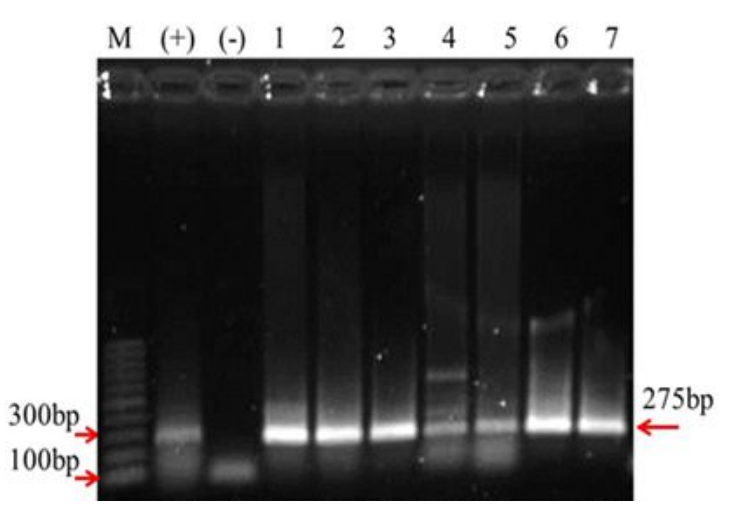

Hình 1. Sản phẩm PCR đặc hiệu gen mã hóa peptidase M1 của HPS.M: thang chuẩn 100 - 1.000 bp; (+): Đối chứng dương; (-): Đối chứng âm; 1 - 7: các mẫu thực địa.

quả dương tính với băng mục tiêu là 275 bp như được thể hiện trong Hình 1.

Như vậy, 21 mẫu trong tổng số 245 mẫu được xét nghiệm cho kết quả dương tính với vi khuẩn HPS, chiếm tỷ lệ 8,6\%. Kết quả này tương đồng với tỷ lệ phát hiện HPS trong nghiên cứu của Teixeira \& ctv. (2011), trong 384 mẫu được thu thập trong giai đoạn 2007-2010 tại Brazil, tác giả đã ghi nhận có 32 mẫu phân lập thành công HPS, chiếm $8,3 \%$. Tuy nhiên, tỷ lệ phát hiện HPS này thấp hơn đáng kể so với nghiên cứu của Tang \& ctv. (2009) khi họ phân tích 2912 mẫu từ heo có triệu chứng viêm phổi, HPS được phân lập đạt 17,1\%. Tại Trung Quốc, trong cuộc kiểm tra 828 trường hợp heo có triệu chứng bệnh đường hô hấp trong thời gian 2003 -2004, tác giả ghi nhận $183 / 828$ trường hợp $(22,1 \%)$ dương tính với HPS (Cai \& ctv., 2005). Tiếp theo sau đó, Zhao \& ctv. (2011) cũng đã khảo sát bằng phương pháp nuôi cấy phân lập với số lượng mẫu lớn (562 mẫu phổi) và đã phát hiện 174 mẫu nhiễm HPS, tương ứng với 30,96\%. Tại Việt Nam, tác giả Lam (2013), khi nghiên cứu về heo PMWS (Hội chứng gầy còm sau cai sữa) cũng ghi nhận trong số 60 ca mổ khám, xét nghiệm đã phát hiện 3 loại vi khuẩn đường hô hấp Pasteurella multocida, Streptococcus spp., và HPS, trong đó tỷ lệ nhiễm HPSđạt $17,5 \%$. Những sự khác biệt về tỷ lệ phát hiện HPS trong những nghiên cứu kể trên có thể do sự khác biệt về số mẫu khảo sát, sự khác nhau về mặt địa lý, các yếu tố về môi trường, thời tiết, qui mô chăn nuôi, hoặc cũng có thể do kỹ năng và điều kiện xét nghiệm.

Trong một khảo sát đại trà khác tại Slovakia, 
Hricinova \& ctv. (2010) đã thu thập ngẫu nhiên 219 mẫu phổi từ lò mổ để nuôi cấy phân lập HPS và tỷ lệ dương tính ghi nhận được là 0,91\% (2/219 mẫu) nhưng khi phát hiện bằng kỹ thuật multiplex PCR thì tỷ lệ này cao hơn là 1,83\% (4/219 mẫu). Tỷ lệ phát hiện HPS cao hơn khi dùng kỹ thuật PCR có lẽ là do PCR phát hiện bộ gen vi khuẩn nên không đòi hỏi vi khuẩn còn sống ở trong mẫu. Tỷ lệ dương tính với HPS trong nghiên cứu này thấp bởi vì mẫu bệnh phẩm được thu thập ngẫu nhiên từ heo mạnh khỏe chứ không tập trung ở các heo có triệu chứng lâm sàng của bệnh đường hô hấp.

\subsection{Kết quả khảo sát sự đề kháng kháng sinh của vi khuẩn HPS}

Sau khi 21 mẫu vi khuẩn HPS được khẳng định bằng các phương pháp sinh hóa cũng như PCR, chúng được nuôi cấy và được dùng để kiểm tra sự đề kháng đối với một số loại kháng sinh thông dụng đang được sử dụng phổ biến trong chăn nuôi hiện nay. Xét nghiệm kháng sinh đồ được thực hiện bằng kỹ thuật khuếch tán trên thạch (Hình 2) với kết quả được trình bày trong Hình 2. Kết quả chỉ ra rằng vi khuẩn HPS thu thập trong thí nghiệm này đề kháng cao nhất với tylosin (91\%), tiếp theo là tilmi$\operatorname{cosin}(81 \%)$, tulathromycin $(62 \%)$, enrofloxacin $(62 \%)$, lincomycin/spectinomycin (57\%), amoxicillin (52\%), florfenicol $(48 \%)$, ceftiofur $(10 \%)$ và thấp nhất là doxycycline (5\%). Tỷ lệ vi khuẩn nhạy cảm với kháng sinh, cao nhất là doxycycline (95\%), ceftiofur (91\%), florfenicol (52\%) và nhạy cảm thấp hơn $50 \%$ đối với amoxycillin (48\%), lincomycin/spectinomycin (43\%), enrofloxacin $(38 \%)$, tulathromycin $(38 \%)$, tilmicosin $(19 \%)$, tylosin (10\%). Kết quả phân tích cho thấy trong 9 loại kháng sinh được sử dụng, 6 loại kháng sinh có tỷ lệ đề kháng cao hơn $50 \%$. Tỷ lệ đề kháng càng cao càng gây ra những thiệt hại lớn hơn về kinh tế, thể hiện ở các khía cạnh như: tốn phí cao hơn trong diều trị bệnh do dùng kháng sinh không còn nhạy cảm, hoặc phải tăng liều lượng kháng sinh sử dụng; tỷ lệ bệnh và tỷ lệ chết tăng cao; vật nuôi bị ảnh hưởng bởi bệnh tật nhiều hơn và lâu hơn làm giảm năng suất...

Vấn đề vi khuẩn đề kháng kháng sinh đang là một trong những chủ đề rất được quan tâm ở nhiều nơi trên thế giới vì hiện tượng đề kháng đang xảy ra ở bất kỳ nước nào, ngay cả ở các nước đã phát triển, là những nơi việc sử dụng kháng sinh được kiểm soát chặt chẽ. Tình hình

\section{TỈ LÊ NHẠY CẢM VÀ ĐỀ KHÁNG VỚI KHÁNG SINH CỦA Haemophilus parasuis}

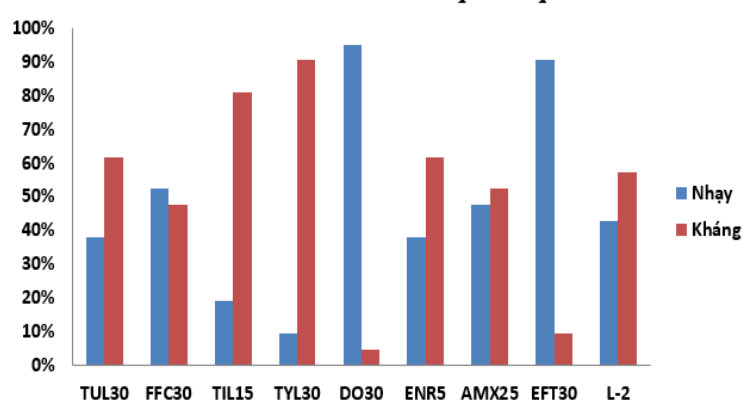

Hình 2. Biểu đồ thể hiện tỷ lệ nhạy cảm và đề kháng với kháng sinh của HPS. Tulathromycin (TUL30), florfenicol (FFC30), tilmicosin (TIL15), tylosin (TYL30), doxycycline (DO30), enrofloxacin (ENR5), amoxicillin (AMX25), ceftiofur (EFT30), lincomycin/spectinomycin (L2).

nhạy cảm với kháng sinh của HPS ở mỗi quốc gia là khác nhau, tuy nhiên mới chỉ có một số ít báo cáo ghi nhận về tình hình đề kháng với kháng sinh của vi khuẩn này. Tại Đan Mạch, các HPS được phân lập đều nhạy cảm với toàn bộ các kháng sinh thử nghiệm (ampicilin, ceftiour, ciprofloxacin, erythromycin, fluorphenicol, penicilin, spectinomycin, tetracycline, tiamulin, tilmicosin và $\mathrm{TMP}+$ sulfamethoxazole) bằng phương pháp xác định MIC (Aarestrup \& ctv., 2004). Tuy nhiên, tại Tây Ban Nha thì trong số 30 mẫu HPS được phân lập đã đề kháng với Trimethoprim+Sulfamethoxazole và enrofloxacin lần lượt là $53,3 \%$ và $20 \%$. Tại Anh Quốc, cũng với 30 mẫu HPS phân lập được thì có $10 \%$ đề kháng với Trimethoprim+Sulfamethoxazole (Fuente \& ctv., 2007). Tại Trung Quốc, người ta ghi nhận có đến $44,5 \%$ và $70,9 \%$ chủng HPS dề kháng lần lượt với trimethoprim+sulfamethoxazole và enrofloxacin (Zhou \& ctv., 2010). Gần đây, Xu \& ctv. (2011) công bố kết quả khảo sát sự đề kháng của HPS với hàng loạt kháng sinh. Tỷ lệ kháng cao nhất là đối với Nalidixic acid (84,8\%), TMP $(67,9 \%)$ và trimethoprim + sulfamethoxazole $(58 \%)$, enrofloxacin $(45,5 \%)$, streptomycin $(48,2 \%)$, tetracycline $(41,1 \%)$, ciprofloxacin $(41,1 \%)$, norfloxacin $(38,4 \%)$, erythromycin $(29,5 \%)$ và benzylpenicillin $(29,4 \%)$. Và chỉ 5 loại kháng sinh có tỷ lệ đề kháng dưới $20 \%$, gồm azithromycin (16\%), chloramphenicol $(14,3 \%)$, rifampicin $(13,4 \%)$, cefotaxime $(8,0 \%)$ và florfenicol $(0 \%)$. Sự khác nhau về tỷ lệ nhạy/kháng kháng sinh của cũng loại vi khuẩn phân lập từ 
Bảng 1. Tỷ lệ đa kháng của vi khuẩn HPS phân lập được đối với một số loại kháng sinh $(\mathrm{n}=21)$

\begin{tabular}{ccl}
\hline $\begin{array}{c}\text { Số chủng } \\
\text { HPS dề kháng }\end{array}$ & $\begin{array}{c}\text { sháng } \\
\text { sinh bị kháng }\end{array}$ \\
\hline 0 & 0 & - \\
0 & 1 & - \\
1 & 2 & TUL + TYL \\
1 & 2 & TUL + TIL \\
1 & 2 & FFC + ENR \\
1 & 3 & TIL + ENR + AMX \\
1 & 3 & TYL + AMX + L2 \\
1 & 4 & FFC + TIL + TYL + ENR \\
2 & 4 & TIL + TYL + ENR + L2 \\
2 & 5 & TUL + FFC + TIL + TYL + L2 \\
1 & 5 & TUL + FFC + TIL + TYL + ENR \\
1 & 5 & TUL + TIL + TYL + ENR + L2 \\
2 & 5 & TUL + TIL + TYL + ENR + AMX \\
1 & 5 & FFC + TIL + TYL + AMX + L2 \\
1 & 6 & FFC + TIL + TYL + AMX + EFT + L2 \\
1 & 6 & TUL + TIL + TYL + ENR + AMX + L2 \\
1 & 6 & TUL + FFC + TIL + TYL + ENR + AMX \\
1 & 7 & FFC + TIL + TYL + DO + ENR + AMX + L2 \\
1 & 7 & TUL + FFC + TIL + TYL + AMX + EFT + L2 \\
1 & 7 & TUL + FFC + TIL + TYL + ENR + AMX + L2 \\
\hline
\end{tabular}

nhiều vùng lãnh thổ khác nhau có thể là do sự khác biệt ở yếu tố di truyền của vi khuẩn và yếu tố môi trường ở từng vùng, từng quốc gia, cũng như thói quen sử dụng kháng sinh trong chăn nuôi cũng như trong xã hội.

Để có cái nhìn tổng quát hơn về hiện trạng đề kháng kháng sinh của 21 phân lập HPS này, tính đa kháng được phân tích và kết quả được trình bày trong Bảng 1 . Kết quả cho thấy các vi khuẩn này đa kháng với ít nhất với 2-7 loại kháng sinh. Số vi khuẩn kháng với 7 loại kháng sinh chiếm đến $33,33 \%$, số kháng với 6 loại chiếm $28,6 \%$ và số kháng với 5 loại chiếm $23,8 \%$. Số liệu này cho thấy vấn đề đề kháng kháng sinh trên HPS là rất nghiêm trọng và cần có những giải pháp cự thể và quyết liệt để ngăn chăn thực trạng này nhằm bảo vệ sức khỏe vật nuôi cũng như bảo vệ sức khỏe con người tốt hơn.

Như vậy, với tình trạng đa kháng kháng sinh như trên, trong số 9 loại kháng sinh được kiểm tra trong nghiên cứu này, chỉ còn 2 loại kháng sinh còn có thể sử dụng được trong điều trị bệnh Glässer do vi khuẩn HPS gây ra với khả năng thành công trên $90 \%$ là doxycycline và ceftiofur.

\section{Kết Luận}

Nghiên cứu phân lập vi khuẩn Haemophilus spp. từ mẫu thu thập trên heo có biểu hiện bệnh đường hô hấp đã ghi nhận tỷ lệ phát hiện vi khuẩn Haemophilus spp. là 20,8\%. Sau khi xét nghiệm với các phản ứng sinh hóa và $\mathrm{PCR}$, tỷ lệ nhiễm Haemophilus parasuis được ghi nhận ở mức $8,6 \%$ trong tổng số 245 cá thể heo được phân tích.

Tất cả các chủng HPS được phân lập đều đề kháng với ít nhất 2 trong 9 loại kháng sinh được khảo sát. Số vi khuẩn kháng với 7 loại, 6 loại và 5 loại kháng sinh chiếm lần lượt 33,33\%,28,6\% và $23,8 \%$.

Chỉ 2 trong số 9 loại kháng sinh còn nhạy với trên $90 \%$ các chủng HPS được kiểm tra là doxycycline và ceftiofur.

\section{Tài Liệu Tham Khảo (References)}

Aarestrup, M. F., Seyfarth, M. A., \& Angen, Q. (2004). Antimicrobial susceptibility of Haemophilus parasuis and Histophilus somni from pigs and cattle in Denmark. Veterinary Microbiology, 101143-101146.

Amano, H., Shibata, M., Kajio, N., \& Morozumi, T. (1994). Pathologic observations of pigs intranasally inoculated with serovar 1, 4 and 5 of Haemophilus para- 
suis using immunoperoxidase method. Journal of Veterinary Medicine Science 56(4), 639-644.

APHA (Animal and Plant Health Agency). (2016). Pig: disease surveillance reports (Animal and Plant Health Agency). Retrieved March 3, 2017 from https://assets.publishing.service.gov.uk/government/ uploads/system/uploads/attachment_data/file/5491 13/pub-survrep-p0216.pdf

Brockmeier, L. S., Halbur, G. P., \& Thacker, L. E. (2002). Porcine respiratory disease complex. In Brogden, K. A., Guthmiller, J. M. (Eds.). Polymicrobial Diseases ( $2^{\text {nd }}$ ed.). Pennsylvania, USA: ASM Press and Washington (DC).

Cai, X., Chen, H., Blackall, P. J., Yin, Z., Wang, L., Liu, Z., \& Jin, M. (2005). Serological characterization of Haemophilus parasuis isolates from China. Veterinary Microbiology 111(3-4), 231-236.

Chiu, X. H. (2017). Establishment of a PCR procedure for detection of Haemophilus parasuis in pigs (Unpublished bachelor's thesis). Nong Lam University, Ho Chi Minh City, Vietnam.

Dayao, D. A. E., Gibson, J. S., Blackall, P. J., \& Turni C. (2016). Antimicrobial resistance genes in Actinobacillus pleuropneumoniae, Haemophilus parasuis and Pasteurella multocida isolated from Australian pigs. Australian Veterynary Journal 94(7), 227-231.

Espinosa, I., Basez, M., Percedo, M. I., \& Martinez, S. (2013). Evaluation of simplified DNA extraction methods for Streptococcus suis typing. Revista de Salud Animal 35(1), 59-63.

Fuente, A. J. M., Tucker, A. W., Navas, J., Blanco, M., Morris, S. J., \& Martin, C. B. G. (2007). Antimicrobial susceptibility patterns of Haemophilus parasuis from pigs in the United Kingdom and Spain. Veterynary Microbiology 120(1-2), 184-191.

Hindler, J. A., Richter, S. S., Bernard, K., Jones, S. B., Castanheira, M., Citron, D. M., Couturier, M. R., Fritsche, T. R., Humphries, R. M., Jorgensen, J. H., Killian, S. B., Kohner, P., Matuschek, E., McDermott, P., \& Patel, S. (2016). CLSI M45 - Methods for antimicrobial dilution and disk susceptibility testing of infrequently isolated or fastidious bacteria ( $3^{\text {rd }}$ ed.). Wayne, Pennsylvania, USA: Clinical and Laboratory Standards Institute.

Howell, K. J., Peters, S. E., Wang, J., Hernandez-Garcia, J.,Weinert, L. A., Luan, S., Chaudhuri, R. R., Angen, Ø., Aragon, V., Williamson, S. M., Parkhill, J., Langford, P. R., Rycroft, A. N., Wren, B. W., Maskell, D. J., \& Tucker, A. W. (2015). Development of a Multiplex PCR Assay for Rapid Molecular Serotyping of Haemophilus parasuis. Journal Clinical Microbiology 53(12), 3812-3821.

Hricinova, M., Holoda, E., Mudronova, D., \& Ondrasovicova, S. (2010). Multiplex PCR assay for detection of Actinobacillus pleuropneumoniae, Pasteurella multocida and Haemophilus parasuis in lung of pig from a slaughterhouse. Folia microbiologica 55(6), 635-640.
Lam, H. T. T. (2013). Pathological findings and prevalence of some co-infected bacteria in pigs affected by the postweaning multisystemic wasting syndrome. Journal of Veterinary Science and Technology 3, 2228.

MacInnes, J. I., Gottschalk, M., Lone, A. G., Metcalf, D. S., Ojha, S., Rosendal, T., Watson, S. B., \& Friendship, R. M. (2008). Prevalence of Actinobacillus pleuropneumoniae, Actinobacillus suis, Haemophilus parasuis, Pasteurella multocida, and Streptococcus suisin representative Ontario swine herds. Canada Journal Veterynary Research 72(3), 242-248.

Markey B., Leonard F., Archambault M., Cullinane A., \& Maguire D. (2013). Haemophilus and Histophilus species. In Clinical veterinary microbiology ( $2^{\text {nd }}$ ed., 349-354). China: Mosby Elsevier. ISBN 978-0-72343237-1.

Nedbalcova, K., Satran, P., Jaglic, Z., Ondriasova, R., \& Kucerova, Z. (2006). Haemophilus parasuis and Glässer's disease in pigs: a review. Veterinarni Medicina 51(5), 168-179.

Nguyen, H. D. (2015). Some infectious diseases of livestock in Mekong delta. National Conference on Animal Husbandry and Veterinary Science in Can Tho, Vietnam: Agricultural Publishing House.

Oliveira, S., \& Pijoan, C. (2004). Haemophilus parasuis: new trends on diagnosis, epidemiology and control. Veterinary Microbiology 99(1), 1-12.

Olvera, A., Calsamiglia, M., \& Aragon, V. (2006). Genotypic diversity of Haemophilus parasuis field strains. Apply Environment Microbiology 72(6), 3984-3992.

Reiner, G., Fresen, C., Bronnert, S., Haack, I., \& Willems, H. (2010). Prevalence of Haemophilus parasuis infection in hunted wild boars (Sus scrofa) in Germany. European Journal Wildlife Research 56(5), 815-818.

Shryock, T. R., Apley, M., Jones, R. N., Lein, D. H., Thornsberry, C., Walker, R. D., Watts, J. L., White, D. G., \& Wu, C.C. (2002). CLSI M31 - A2 - Performance Standards for Antimicrobial Disk and Dilution Susceptibility Tests for Bacteria Isolated from Animals (2 ${ }^{\text {nd }}$ ed.). Wayne, Pennsylvania, USA: Clinical and Laboratory Standards Institute.

Tang, X., Zhao, Z., Hu, J., Wu, B., Cai, X., He, Q., \& Chen, H. (2009). Isolation, antimicrobial resistance and virulence genes of Pasteurella multocida strains from swine in China. Journal Clinical Microbiology 47(4), 951-958.

Teixeira, M. L., Kuchiishi, S. S., \& Brandelli, A. (2011). Isolation of Haemophilus parasuis from diagnostic samples in the South of Brazil. Brazil Journal Veterinary Pathology 4(2), 122-125.

Tonpitak, W. (2010). Isolation of A. pleuropneumoniae serotype 15-like strain from a porcine tonsil in Thailand: A case report. Thai Journal Veterinary Medicine 40(3), 343-348. 
Wang, Z., Zhao, Q., Wei, H., Wen, X., Cao, S., Huang, X., Wu, R., Yan, Q., Huang, Y., \& Wen, Y. (2017). Prevalence and seroepidemiology of Haemophilus parasuis in Sichuan province, China. PeerJ 5, e3379. doi: $10.7717 /$ peerj.3379.

Xu, C., Zhang, J., Zhao, Z., Guo, L., Zhang, B., Feng, S., Zhang, L., \& Liao, M. (2011). Antimicrobial susceptibility and PFGE genotyping of Haemophilus parasuis isolates from pigs in South China (2008-2010). Journal Veterinary Medicine Science 73(8), 1061-1065.
Zhao, Z., Wang, C., Xue, Y., Tang, X., Wu, B., Cheng, X., He, Q., \& Chen, H., 2011. The occurrence of Bordetella bronchiseptica in pigs with clinical respiratory disease. Veterinary Journal 188(3), 337-340.

Zhou, X., Xu, X., Zhao, Y., Chen, P., Zhang, X., Chen, H., \& Cai X. (2010). Distribution of antimicrobial resistance among different serovars of Haemophilus parasuis isolates. Veterinary Microbiology 141(1-2), 168173 . 